\title{
Penyuluhan Pemanfaatan Sampah Sebagai Bahan Kosmetika Alami di Desa Rempung Kec. Pringgasela
}

\author{
Abdul Rahim $\left.{ }^{*}\right) 1$, Hartini Haritani, ${ }^{1}$ Wiwit Pura Nurmayanti ${ }^{2}$, Ersi Arviana Ihsan ${ }^{1}$, \\ Puspawan Hariadi ${ }^{1}$ \\ ${ }^{1}$ Farmasi Fakultas Kesehatan Universitas Hamzanwadi \\ ${ }^{2}$ Statistik Fakultas Matematika dan Ilmu Alam Universitas Hamzanwadi \\ *)Corresponding author, $\equiv$ rahimkhanrewa12@gmail.com
}

Artikel Histori:

Diterima 19/07/2020;

Revisi 20/08/2020;

Publish 23/09/2020
Kata kunci: Kosmetik, Penyuluhan, Rempung, Sampah,

\begin{abstract}
Abstrak
Tujuan utama Pengabdian ini yaitu membangun kesadaran serta menumbuhkan jiwa wirausaha masyarakat dalam pemanfaatan sampah buah sebagai kosmetika, sehaingga dapat meminimalisis sampah di masyarakat. Kelompok yang menjadi target utama pelaksanaan program pelatihan ini ialah warga Desa Rempung. Metode yang dilakukan berupa pemberian informasi (edukasi/penyuluhan) mengenai pemanfaatan sampah buah sebagai jamu kesehatan atau bahan baku kosmetika merupakan komponen kunci untuk meningkatkan pemahaman dan pemanfaatan herbal. Selain itu juga dapat meningkatkan nilai ekonomis nilai ekonomi tanaman herbal di kawasan tersebut. Berdasarkan hasil pelaksanaan program pengabdian kepada masyarakat dapat disimpulkan bahwa kegiatan penggunaan obat tradisonal dan pembuatan kosmetik alami berjalan dengan baik dan lancar. Hal ini diketahui dari tingkat kehadiran dan keaktifan para peserta. Para peserta yang hadir sangat antusias dalam mendengarkan penjelasan dan aktif bertanya terkait penggunaan obat dan penanganannya dan membuat produk masker bayam yang akan menigkatkan perekonomian masyarakat.
\end{abstract}

\section{PENDAHULUAN}

Analisis Situasi

Sampah adalah sesuatu bahan atau benda padat yang sudah tidak dipakai lagi oleh manusia, atau benda padat yang sudah tidak digunakan lagi dalam suatu kegiatan manusia dan dibuang (Setyaji, Hidayat, Sukmaningrum, \& Hawa, 2017). Perilaku membuang sampah disembarang tempat seperti disungai, kebun, maupun laut masih banyak dilakukan. Masyarakat jarang mengolah sampah-sampah tersebut menjadi nilai barang yang ekonomis (Wesnawa, Christiawan, \& Suarmanayasa, 2017). Untuk dapat meningkatkan nilai tambah dari sampah, diperlukan sarana yang cukup dan memadai serta kesadaran masyarakat dalam melakukan pengelolaan sampah yang baik. Salah satu pengelolaan persampahan yaitu menjadikan sampah sebagai kosmetika alami (Izzah, 2019). Kosmetika merupakan suatu bahan atau sediaan yang 
dimaksudkan untuk digunakan pada bagian luar tubuh manusia (epidermis, rambut, kuku, bibir dan organ genital bagian luar) atau gigi dan mukosa mulut terutama untuk membersihkan, mewangikan, mengubah penampilan dan atau memperbaiki bau badan atau melindungi atau memelihara tubuh pada kondisi baik (Faria-Silva et al., 2020). Kosmetika bahan dasar sampah ini meliputi kosmetika pada wajah karena wajah merupakan bagian tubuh yang paling sering diperhatikan dibandingkan dengan bagian tubuh lainnya, terutama bagi wanita (Kusumocahyo, Tangguh, Annelies, \& Sutanto, 2019).

Penuaan kulit merupakan proses alami yang tidak dapat dihindari, dimana manusia akan mengalami kelambatan proses pembaruan sel kulit dan produksi kolagen, melemahnya struktur pendukung internal dan lapisan pelindung alami kulit (Afifah, Suparno, Haditjaroko, \& Tarman, 2019). Pelambatan proses regenerasi kulit disebabkan oleh faktor lingkungan dan gaya hidup. Stres oksidatif intraseluler dan ekstraseluler yang disebabkan oleh reactive oxygen species (ROS), dapat mempercepat penuaan kulit, yang ditandai dengan keriput dan pigmentasi (Masaki, 2010).

Faktor lain yang mempengaruhi proses penuaan adalah enzim elastase dan kolagenase (Välimaa et al., 2019). Paparan sinar Ultraviolet (UV) dan ROS yang berlebihan dapat mempercepat proses aktivasi enzim elastase yang memegang penting dalam proses degradasi elastin, dimana elastin merupakan komponen utama dari serat elastis pada jaringan ikat dan tendon yang bersama-sama dengan serat kolagen, membentuk jaringan bawah epidermis (Torres, Kraan, \& Domínguez, 2019; Zhao \& Zhang, 2020). Adanya aktivasi dari enzim tersebut maka protein matriks jaringan ikat utama, seperti elastin, kolagen, proteoglikan, dan keratin akan dipecah sehingga dapat memicu terjadinya kerutan pada kulit (Purwanto \& PermanaCitra, 2019). Selain itu, sinar UV yang berlebihan dapat menginduksi enzim tyronase sehingga dapat menginisiasi pigmentasi kulit, yang disebabkan oleh pembentukan melanin pada lapisan kulit (Kim et al., 2008).

Menjaga pola hidup sehat, menghindari paparan sinar UV yang berlebihan, mengkonsumsi dan memakai produk perawatan kulit (skin care) secara topikal yang mengandung senyawa antioksidan dapat menghambat penuaan dini pada kulit (Hadi et al., 2018; Schmittgen, Groher, Klein, Hunsche, \& Noga, 2020). Sudah banyak penelitian yang membuktikan bahwa antioksidan dapat mencegah kerusakan sel dan menghambat penuaan dini (Fusco, Colloca, Monaco, \& Cesari, 2007). Masyarakat Indonesia sejak dahulu sudah memanfaatkan tumbuhan sebagai obat, dan banyak digunakan sebagai bahan kosmetik serta perawatan kulit. Selain itu, meningkatnya trend "back to nature" dimana masyarakat percaya bahwa senyawa aktif dari bahan alam relatif lebih aman dibandingkan senyawa kimia sintetik.

Keanekaragaman hayati yang besar di Indonesia merupakan salah satu faktor pendukung pengembangan produk perawatan kulit dari bahan alam. Kecamatan Pringgasela Kabupaten lombok timur merupakan salah satu daerah di lombok timur dengan ketinggian kurang lebih 0150 meter di atas permukaan laut, sehingga termasuk dataran rendah dengan suhu dan kelembapan yang cukup tinggi. Suhu dan kelembapan serta sinar matahari sangat mempengaruhi kesehatan kulit. Dimana permasalahan yang sering timbul adalah hiperpigmentasi, dehidrasi dan kulit kering.

\section{Solusi dan Target}

Tujuan utama dari Pengabdian ini yaitu membangun kesadaran serta menumbuhkan jiwa masyarakat yang sadar akan kesehatan terutama dalam pemanfaatan sampah buah sebagai kosmetika, sehaingga dapat meminimalisis sampah di masyarakat. Dengan pemberian edukasi yang diberikan kepada masyarakat ini diharapkan dapat memberikan edukasi juga kepada keluarga sehingga apa yang didapatkan dari sosialisasi dapat bermanfaat juga masyarakat keluarga. Selain itu, melalui kegiatan ini diharapkannnya para peserta dapat menjadi 


\section{Suluah Bendang: Jurnal Ilmiah Pengabdian Kepada Masyarakat}

Vol.20, No.3, 2020

Abdul Rahim, Hartini Haritani, Wiwit Pura Nurmayanti, Ersi Arviana Ihsan, Puspawan

penghubung untuk menyampaikan informasi dilingkungan desa sekitar lainnya agar lebih tahu dan paham cara memanfaatkan sampah buah sebagai kosmetika.

Berikut bentuk dan ruang lingkup program dan target capaian pengabdian masyarakat di masyarakat Rempung Kecamatan Pringgasela Kab. Lombok Timur - NTB diantaranya:

Tabel 1. Ruang lingkup Program \& Target Sasaran

\begin{tabular}{lcl}
\multicolumn{1}{c}{ JenisKegiatan } & Sasaran & \multicolumn{1}{c}{ Target Capaian Kegiatan } \\
$\begin{array}{l}\text { Edukasi Perilaku hidup } \\
\text { bersih dan sehat }\end{array}$ & $\begin{array}{c}\text { Masyarakat Desa } \\
\text { Rempung }\end{array}$ & $\begin{array}{l}\text { Masyarakat/ warga mengerti bagaimana } \\
\text { perilaku hidup bersih dan sehat }\end{array}$ \\
$\begin{array}{l}\text { Edukasi pencegahan } \\
\text { covid-19 }\end{array}$ & $\begin{array}{c}\text { Masyarakat Desa } \\
\text { Rempung }\end{array}$ & $\begin{array}{l}\text { Masyarakat/warga mengerti tentang } \\
\text { pentingnya dan cara melindungi diri } \\
\text { agar tidak terkena virus corona }\end{array}$ \\
$\begin{array}{l}\text { Pembagian masker dan } \\
\text { vitamin C }\end{array}$ & $\begin{array}{c}\text { Masyarakat Desa } \\
\text { Rempung }\end{array}$ & $\begin{array}{l}\text { Masyarakat tergerak untuk menggunkan } \\
\text { masker dan daya tahan tubuhnya } \\
\text { meningkat }\end{array}$ \\
$\begin{array}{l}\text { Edukasi Obat } \\
\text { Tradisional dan } \\
\text { Kosmetika }\end{array}$ & Masyarakat Desa \\
Rempung & $\begin{array}{l}\text { Masyarakat mampu mengkosumsi obat } \\
\text { yang baik dan benar dan membuat } \\
\text { kosmetika alami }\end{array}$ \\
\hline
\end{tabular}

\section{METODE PELAKSANAAN}

\section{Kelompok Sasaran}

Kelompok yang menjadi target utama pelaksanaan program pelatihan ini ialah Kader PKK (Pembinaan Kesejahteraan Keluarga) dan warga Desa Rempung Kecamatan Pringgasela Kabupaten lombok timur. Pemilihan lokasi tersebut dengan pertimbangan mengingat penyebaran masyarakat tersebut mencakup area yang cukup luas dan meliputi bebrapa kecamatan besar di wilayah kabupaten Lombok Timur, sehingga pengetahuan dan pemahaman tentang pemnafaatn sampah sebagai kosmetika diharapkan dapat tersebar lebih luas di masyarakat.

\section{Waktu Pelaksanaan}

Pelaksanaan kegiatan ini direncanakan pada bulan agustus 2020. Pemilihan bulan ini dengan beberapa pertimbangan pertama pada rentang waktu ini secara internal aktifitas perkuliahan masih belum dimulai sehingga peluang untuk para Dosen ikut berkontribusi sangat besar.

\section{Prosedur Kerja}

Kegiatan pelayanan kefarmasian (Pharmaceutical care) yang termasuk kedalam metode pendidikan masyarakat berupa pemberian informasi (edukasi/penyuluhan) mengenai pemanfaatan sampah buah sebagai jamu kesehatan atau bahan baku kosmetika merupakan komponen kunci untuk meningkatkan pemahaman dan pemanfaatan herbal. Selain itu juga dapat meningkatkan nilai ekonomis nilai ekonomi tanaman herbal di kawasan tersebut.

Dilakukan program penyuluhan/edukasi berupa pemberian materi, demo cara membuat masker bayam. Kader PKK (Pembinaan Kesejahteraan Keluarga) dan warga Desa Rempung Kecamatan Pringgasela Kabupaten lombok timur Kegiatan penyuluhan ini merupakan kegiatan program pengabdian kepada masyarakat (PkM) dengan tahapan kegiatan sebagai berikut: dimulai dengan survey tempat, proses perizinan, penyusunan materi edukasi dan persiapan alat bahan untuk demo pembuatan masker bahab dasar sampah buah. Kegiatan utama adalah 
penyuluhan dengan materi mengenai pemanfaatan sampah buah untuk kosmetika alami dan demo pembuatan masker beras kencur, serta kegiatan minum jamu bersama. Kegiatan dilanjutkan dengan pengambilan dan analisis data. Pengambilan data dilakukan dengan pemberian kuesioner pada Kader PKK yang mengikuti kegiatan penyuluhan. Data yang diperoleh kemudian direkapitulasi untuk dilanjutkan dengan analisis.

Dalam pelaksanaannya, program ini akan dilaksanakan dalam beberapa kegiatan, yaitu:

Sosialisasi Pengetahuan dan Pemahaman Tentang sampah buah sebagai kosmetika

Beberapa langkah yang dilakukan pada kegiatan ini adalah:

Penentuan lokasi

Kegiatan ini rencananya akan dilaksanakan di lokasi desa Rempung. Pemilihan lokasi ini karena pertama, pemahaman masyarakat secara luas tentang pemanfaatan bahan sampah buah yang dapat digunakan sebagai kosmetika masih tergolong rendah sehingga diharapakan dengan kegiatan ini dapat meningkatkan pengetahuan dan pemahaman bagaimana memanfaatkan sampah buah sebagai kosmetika dapat ditingkatkan.

Koordinasi dengan Mitra Kegiatan

Dalam tahapan ini, peneliti berkoordinasi dengan pihak desa mitra dalam proses organisasi pelaksanaan kegiatan, mulai dari mengkoordinasi waktu pelaksanaan, skema acara, mengumpulkan peserta, sampai dengan penyediaan sarana dan prasarana kegiatan.

Sosialisasi

Pada waktu yang telah ditentukan, Tim sosialisasi memberikan penyampaian materi tentang pemanfaatn samapah buah sebagai kosmetika dan demo pembuatan masker bayam, serta kegiatan pola hidup bersih. Dalam proses ini, tim menghadirkan nara sumber dari rekan Dosen yang sebagian besar adalah apoteker herbal guna memberikan penguatan kepada peserta. Sehingga sosialisasi ini dilakukan oleh ahlinya.

Pendampingan Pemanfaatan sampah buah sebagai kosmetika

Setelah proses sosialisasi dilaksanakan, maka pada tahap berikutnya kepada peserta akan dilakukan pendampingan bagaimana Kegiatan pemanfaatan herbal sampah buah sebagai kosmetika dapat dilakukan seterusnya oleh masyarakat. Tim juga sudah mempersiapkan contoh-contoh produk yang akan dipasarkan dan dikenalkan dalam pelatihan ini. Metode yang digunakan dalam pelatihan ini adalah demonstrasi dan kerja mandiri. Tahap akhir dari kegiatan ini adalah monitoring pelaksanaan kegiatan.

Monitoring Pemanfaatkan sampah buah sebagai kosmetika

Dalam kegiatan monitoring sebagai penutup atau kegiatan akhir dari kegiatan ini, tim akan mengevaluasi pemahaman peserta tentang bagaimana pemanfaatan sampah buah sebagai kosmetika, selanjutnya memberikan buku saku penggunaan obat yang baik dan benar sebagai acuan mereka dalam penggunaan obat. Sebagai penguatan terhadap kegiatan ini akan diberikan juga memberikan leaflet Pemanfaatan sampah buah sebagai kosmetika kepada kepala desa.

\section{HASIL DAN PEMBAHASAN}

Pelaksanaan Program

Pelaksanaan kegiatan pengabdian masyarakat dilakukan di desa Rempung di kecamatan Pringgasela, Kabupaten Lombok Timur. Kegitan ini bertemakan edukasi pemanfaatan sampah buah sebagai bahan kosmetika alami. Kegiatan ini diawali dengan melakukan kunjungan ke desa rempung dengan tujuan untuk memastikan kesiapan desa dalam menerima kegiatan yang akan diberikan. Pelaksanaan dilakukan setelah menyesuaikan jadwal dengan pihak desa. Setelah dilakukannya survey lokasi dan penetapan waktu pelaksanaan kegiatan, dilakukan persiapan-persipan pra kegiatan. Persiapan itu meliputi persiapan teknis dan non-teknis. Persiapan teknis seperti penyiapan alat-lat dan bahan demosntrasi pembuatan kosmetik, beberapa hal seperti mencetak pamflet dan banner yang akan digunakan saat sosialisasi. 


\section{Suluah Bendang: Jurnal Ilmiah Pengabdian Kepada Masyarakat}

Vol.20, No.3, 2020

Abdul Rahim, Hartini Haritani, Wiwit Pura Nurmayanti, Ersi Arviana Ihsan, Puspawan

Hariadi

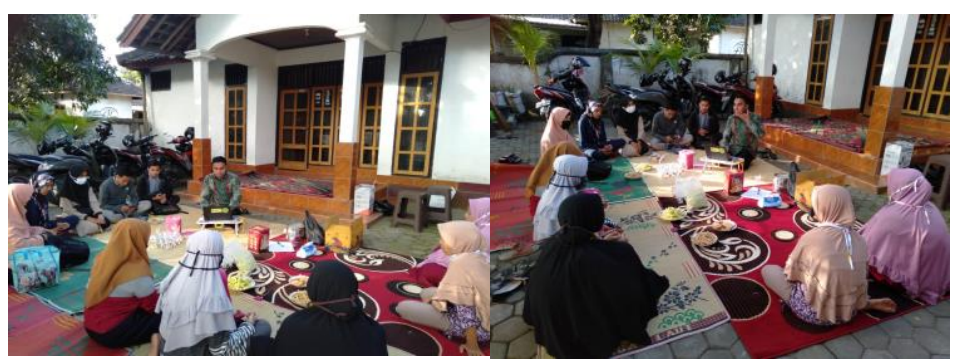

Gambar1. Pelaksanaan pemberian edukasi pneggunaan Obat Tradisional

Edukasi dengan cara penyuluhan tentang penggunaan obat tradisonal dan pembuatan kosmetik alami. Kegiatan dilaksanakan di salah satu rumah warga. Total peserta yang hadir yaitu 15 Masyarakat. Proses kegiatan sosialisasi berjalan sesuai jadwal yang telah ditentukan dan disepakati bersama dan terlihat masyarakat desa sangat antusias terhadap kegiatan yang diadakan oleh pihak program studi farmasi fakultas kesehatan universitas hamzanwadi. Hal ini terlihat dari peserta yang hadir dan keaktifan dari masyarakat untuk ikut serta dalam bagian tanya jawab setelah penyampaian materi.

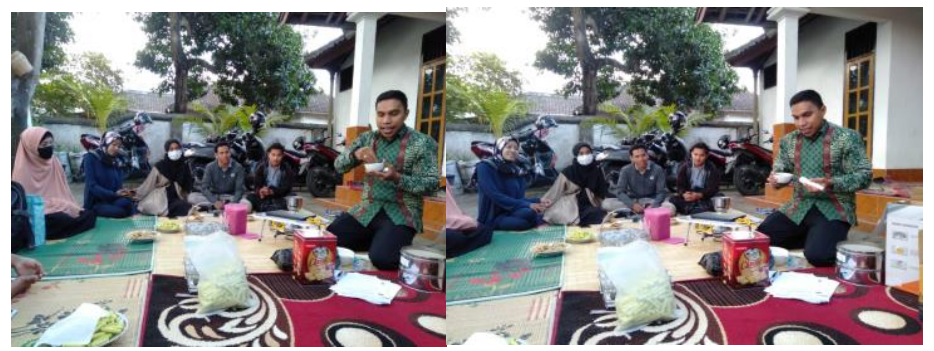

Gambar 2. Pelaksanaan pemberian edukasi dan demonstrasi pembuatan kosmetik

Tujuan pelaksanaan sosialisasi ini untuk dapat memberikan pembelajaran terhadap penggunaan obat yang baik dan benar kepada orang-orang yang bisa dianggap paham terkait bagaimana penggunaan obat, dan bertujuan agar para siswa bisa menjadi contoh bagi masyarakat sekitar untuk dapat berperilaku sehat dengan menggunakan obat yang. Setelah pelaksanaan sosialisasi ini, dilakukan pembimbingan kepada para siswa untuk dap at menjadi agen kesehatan bagi masyarakat daerah setempat dengan mendapatkan pelatihan secara berkesinambungan.

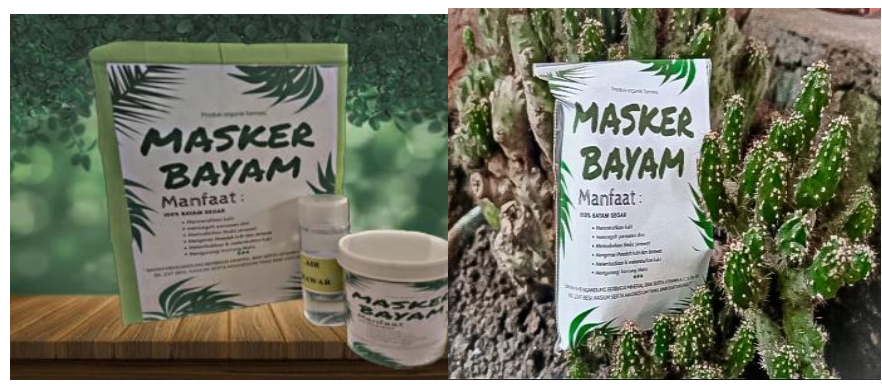

Gambar3. Contoh Produk Kosmetik Alami

Dengan adanya bimbinganpembuatan masker ini, diharapkan masyarakat mampu menjadi pengusaha kosmetik alami yang mengerti bagaimana cara membuat kosmetik yang 
baik dan benar. Selain diberikannya bimbingan, masyarakt juga dibekali dengan adanya materi dalam bentuk sediaan jadi sepertimasker bayam untuk dapat dipergunakan dalam proses penyebaran informasi ke masyarakat lainnya.

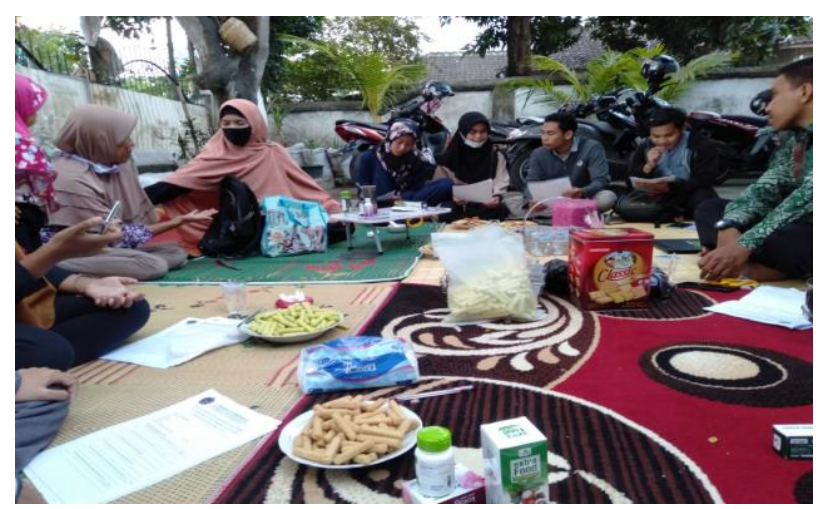

Gambar 4. Pelaksanaan Pemberian Edukasi Perilaku Hidup Sehat

Pelaksanaan edukasi ini dimaksudkan untuk dapat meningkatkan pemahaman terkait penggunaan obat tradisional dan pola hidup sehat dan protocol Covid-19 benar. Hal ini merupakan salah satu pekerjaan rumah yang besar, karena kesadaran masyarakat terkait protocol covid-19 masih sangat kurang. Hal ini terbukti dengan penggunaan obat-obat tradisional yang masih tergolong diabaikan karena tidak termasuk obat dari dokter dan penggunaan yang harus dipantau namun masih digunakan secara bebas. Dari materi yang disampaikan, para peserta mendapatkan ilmu terkait penggunaan obat tradisional, pembuatan kosmetik alami, edukasi protocol covid-19 dan pola hidup sehat untuk menghindari virus covid-19.

Faktor-Faktor Yang Berpengaruh Terhadap Pelaksanaan Kegiatan

Faktor pendukung

Dalam pelaksanaan kegiatan edukasi pembuatan kosmetika alami dapat berjalan dengan baik karena adanya dukungan yang sangat baik dari pihak sekolah tujuan untuk dapat terselenggaranya kegiatan ini dan terutama antusiasme serta konsistensi dari para peserta yang mengikuti kegiatan. Selain itu faktor pendukung lain terselenggaranya kegiatan ini adalah dukungan penuh dari fakultas kesehatan dan program studi farmasi untuk dapat dilaksanakan Faktor penghambat

Dalam pelaksanaan kegiatan ini terdapat beberapa faktor penghambat terlaksananya kegiatan. Faktor-faktor tersebut seperti kurangnya ketertarikan masyarakat yang terhadap obat-obatan, keterbatasan alat di lokasi. Harapan kami dengan pengabdian ini dapat membuka wawasan masyarakat yang diperoleh adalah bertambahnya keilmuan bagi para Para Masyarakat tentang tentang penggunaan obat tradisonal dan pembuatan kosmetik alami dan Ilmu yang diperoleh pada Pengabdian Masyarakat kali ini diharapkan mampu memberikan semangat baru bagi kita dalam menyampaikan materi dan motivasi serta berkontribusi bagi generasi muda, baik dilingkungan sekolah, kampus dan keluarga.

\section{SIMPULAN}

Berdasarkan hasil pelaksanaan program pengabdian kepada masyarakat dapat disimpulkan bahwa kegiatan penggunaan obat tradisonal dan pembuatan kosmetik alami berjalan dengan baik dan lancar. Hal ini diketahui dari tingkat kehadiran dan keaktifan para peserta. Para peserta yang hadir sangat antusias dalam mendengarkan penjelasan dan aktif bertanya terkait penggunaan obat dan penanganannya. Sosialisasi ini meningkatkan pemahaman peserta tentang pengelolaan obat dengan benar. Hasil dari kegiatan ini adalah diharapkan bagi peserta 


\section{Suluah Bendang: Jurnal Ilmiah Pengabdian Kepada Masyarakat}

Vol.20, No.3, 2020

Abdul Rahim, Hartini Haritani, Wiwit Pura Nurmayanti, Ersi Arviana Ihsan, Puspawan

Hariadi

dapat menerapkan pengetahuan yang telah diperoleh dalam lingkungan keluarga dan masyarakat. Hal ini dapat mendukung terwujudnya program pemerintah dalam peningkatan pelayanan kesehatan bagi masyarakat. Diperlukan adanya proses sosialisasi yang lebih berkesinambungan pada masyarakat, agar informasi yang didapatkan masyarakat tentang hal ini bisa lebih banyak dan berkelanjutan, diperlukan adanya dukungan dari pihak yang berwenang (pemerintah) agar proses ini bisa lebih terorganisir sehingga lebih mudah diterapkan.

\section{REFERENSI}

Afifah, A., Suparno, O., Haditjaroko, L., \& Tarman, K. (2019). Utilisation of fish skin waste as a collagen wound dressing on burn injuries: A mini review. https://doi.org/10.1088/17551315/335/1/012031

Faria-Silva, C., Ascenso, A., Costa, A. M., Marto, J., Carvalheiro, M., Ribeiro, H. M., \& Simões, S. (2020). Feeding the skin: A new trend in food and cosmetics convergence. Trends in Food Science \& Technology, 95, 21-32.

Fusco, D., Colloca, G., Monaco, M. R. Lo, \& Cesari, M. (2007). Effects of antioxidant supplementation on the aging process. Clinical Interventions in Aging, 2(3), 377.

Hadi, F., Mustakim, A., Yunianto, I. T., Nur, H. I., Boyke, C., Wuryaningrum, P., ... Ilham, M. B. (2018). Utilization of shell waste as the accelerate admixture on paving in order to improve the quality of the living environment of the kenjeran coastal community. International Journal of Civil Engineering and Technology. Retrieved from https://www.scopus.com/inward/record.uri?eid=2-s2.0-

85054489469\&partnerID=40\&md5=b443d319cd5e2fd4a6d8e15e76534009

Izzah, N. (2019). Pemanfaatan Al-Hasyarât Untuk Kosmetik. Al-Mizan: Jurnal Hukum Dan Ekonomi Islam, 3(1), 119-137.

Kim, Y. H., Chung, C. B., Kim, J. G., Ko, K. Il, Park, S. H., Kim, J.-H., ... Kim, K. H. (2008). Anti-wrinkle activity of ziyuglycoside I isolated from a Sanguisorba officinalis root extract and its application as a cosmeceutical ingredient. Bioscience, Biotechnology, and Biochemistry, 72(2), 303-311.

Kusumocahyo, S. P., Tangguh, P., Annelies, C. D., \& Sutanto, H. (2019). Utilization of coffee silverskin by-product from coffee roasting industry through extraction process for the development of antioxidant skin gel. Journal of Cosmetic Science. Retrieved from https://www.scopus.com/inward/record.uri?eid=2-s2.0-

85076397692\&partnerID $=40 \& \mathrm{md} 5=\mathrm{ec} 71984138 \mathrm{e} 697665879 \mathrm{~b} 13 \mathrm{dd} 12 \mathrm{~b} 211 \mathrm{~d}$

Masaki, H. (2010). Role of antioxidants in the skin: anti-aging effects. Journal of Dermatological Science, 58(2), 85-90.

Purwanto, P., \& Permana-Citra, A. D. (2019). Recycling and processing of solid waste into products of the cosmetic packaging industry. https://doi.org/10.1088/1742$6596 / 1295 / 1 / 012042$

Schmittgen, S., Groher, T., Klein, S., Hunsche, M., \& Noga, G. (2020). Solanaceous crops: A sustainable source of valuable bioactive leaf compounds? Acta Horticulturae. https://doi.org/10.17660/ActaHortic.2020.1275.20

Setyaji, A., Hidayat, N., Sukmaningrum, R., \& Hawa, F. (2017). Pemanfaatan Sampah Rumah 
Tangga Menjadi Barang Serbaguna. Seminar Nasional Hasil-Hasil Pengabdian 2017.

Torres, M. D., Kraan, S., \& Domínguez, H. (2019). Seaweed biorefinery. Reviews in Environmental Science and Biotechnology. https://doi.org/10.1007/s11157-019-09496-y

Välimaa, A.-L., Mäkinen, S., Mattila, P., Marnila, P., Pihlanto, A., Mäki, M., \& Hiidenhovi, J. (2019). Fish and fish side streams are valuable sources of high-value components. Food Quality and Safety. https://doi.org/10.1093/fqsafe/fyz024

Wesnawa, I. G. A., Christiawan, P. I., \& Suarmanayasa, I. N. (2017). Membangun Perilaku Sadar Ekologis dan Ekonomis Ibu Rumah Tangga melalui Reorientasi Pemanfaatan Sampah Perumahan di Btn Banyuning Indah. Jurnal Abdimas, 21(1), 29-40.

Zhao, Z.-L., \& Zhang, Y.-Q. (2020). Greener degumming production of layered sericin peptides from a silkworm cocoon and their physicochemical characteristics and bioactivities in vitro. Journal of Cleaner Production. https://doi.org/10.1016/j.jclepro.2020.121080 